\title{
ДОСЛІДЖЕННЯ АНТИМІКРОБНОї АКТИВНОСТІ КОНСЕРВАНТІВ 3 МЕТОЮ РОЗРОБКИ СКЛАДУ КОМБІНОВАНОГО ГЕЛЮ ДЛЯ МІСЦЕВОГО ЛІКУВАННЯ OחIKIB
}

\author{
Б. В. Павлюк ${ }^{1}$, О. Я. Лукашів ${ }^{2}$, О. В. Покришко ${ }^{1}$, М. Б. Чубка ${ }^{1}$, Т. А. Грошовий ${ }^{1}$ \\ Тернопільський національний медичний університет імені І. Я. Горбачевського \\ МОЗ України ${ }^{1}$ \\ ДП «Тернопільський науково-виробничий центр стандартизації, метрології та \\ сертиярікації»² \\ bohdana.vons@gmail.com
}

\section{ІНФОРМАЦІЯ}

Надійшла до редакції / Received: 29.08.2019

Після доопрацювання / Revised: 12.09.2019

Прийнято до друку / Accepted: 17.09 .2019

\section{Ключові слова:}

гель;

опіки;

консерванти;

антимікробна активність;

мікробіологічні дослідження.

\begin{abstract}
АНОТАЦІЯ
Мета роботи. Дослідження активності антимікробних консервантів у зразках гелю 3 водним витягом із ксенодерми та лідокаїну гідрохлоридом для місцевого лікування опіків.

Матеріали і методи. При дослідженні використовували методику оцінки есрективності антимікробних консервантів відповідно до вимог ДФУ. Як тесткультури використовували такі мікроорганізми: Staphylococcus aureus ATCC 25923, Escherichia coli 055K59 №3912/41, Pseudomonas aeruginosa ATCC 2853 (F51), Candida albicans ATCC 885-653, Aspergillus brasiliensis ATCC 16404.

Результати й обговорення. У результаті проведених досліджень встановлено есрективність досліджуваних антимікробних консервантів (ніпагін/ніпазол, «cosgard», спирт фенілетиловий, бензалконію хлорид) різних концентрацій у модельних зразках гелів із водним витягом із ксенодерми та лідокаїном гідрохлоридом. Досліджувані зразки гелів відповідали вимогам ДФУ (друге вид., том 1, п. 5.1.3) за показником «Ефективність антимікробних консервантів» для лікарських засобів для зовнішнього застосування.

Висновок. Найбільш прийнятним консервантом, згідно 3 отриманими результатами, обрано спирт френілетиловий у концентрації 0,4 \%, що зумовлено проявом його високої антимікробної активності у даній фрармацевтичній композиції, фрізіологічною безпечністю, економічністю, а також можливістю його використання як ароматизатора.
\end{abstract}

Вступ. Лікування опікових ран все ще залишається проблемою сучасної медицини і для ії̈ вирішення у всіх фразах ранового процесу рекомендоване застосування м'яких лікарських форм (МЛФ) [1].

Важливе значення при оцінці якості лікарських засобів (ЛЗ) є мікробіологічний контроль, адже потрапляння у склад МЛФ мікроорганізмів (грампозитивних бактерій - S. aureus; грамнегативних культур - E. coli, $P$. aeruginosa; культури пліснявих та дріжджоподібних грибів роду C. albicans ma A. brasiliensis) у процесі виробництва, зберігання чи використання може призвести до втрати стабільності продукту (розшарування, утворення цвілі) чи до зниження терапевтичної ефрективності без наявних візуальних змін [2]. 
Фармацевтична технологія, біофармація, гомеопатія Pharmaceutical technology, biopharmacy, homeopathy

Використання Л3, які містять мікроорганізми, є небезпечним, оскільки може призвести до зниження чи відсутності терапевтичного ефекту ЛЗ або до виникнення побічних реакцій та нових захворювань. Тому стабільність лікарських препаратів $€$ важливим показником їхньої якості, оскільки забезпечує збереження їхніх терапевтичних та профрілактичних властивостей у процесі зберігання [3].

Тому використання консервантів - природних або синтетичних речовин, які вводять у склад різних ЛЗ для продовження їхнього терміну придатності, $€$ важливим етапом у створенні нових ЛЗ та вдосконаленні існуючих. Додавання консервантів, особливо у склад засобів, які мають великий вміст води, запобігає змінам і деструкції мікроорганізмами впродовж зберігання і значною мірою запобігає мікробному контамінуванню [4].

Відповідно до вимог Державної Фармакопеї України (ДФУ), яка гармонізована з Європейською Фармакопеєю (ЄФ), на стадії розробки МЛФ слід одержати дані, що підтверджують необхідність застосування антимікробних консервантів та ефективність їхньої дії, від якої залежить захист препарату від мікробного забруднення при виробництві, зберіганні та використанні [5].

Мета роботи - дослідження активності антимікробних консервантів у зразках гелів з водним витягом 3 ксенодерми та лідокаїну гідрохлоридом для місцевого лікування опіків.

Матеріали і методи. Ефективність антимікробних консервантів вивчали відповідно до методики оцінки та вимог ДФУ [6]. Як рефрерент-штами використовували такі мікроорганізми: грампозитивні коки Staphylococcus aureus ATCC 25923, грамнегативні палички Escherichia coli 055K59 №3912/41 та Pseudomonas aeruginosa ATCC 2853 (F51), дріжджові та цвілеві гриби Candida albicans ATCC 885-653 та Aspergillus brasiliensis ATCC 16404.

Перед проведенням експериментів перевіряли якість поживних середовищ за їхніми властивостями (табл. 1).
Поживні середовища інокулювали незначною кількістю тест-штамів мікроорганізмів (10-10² колонієутворювальних одиниць на 1 мл середовища - КУО/мл).

Всі досліджувані культури мікроорганізмів відповідали таксономічному позначенню штаму, а морфологія колоній при культивуванні на поживних середовищах і морфологія клітин при мікроскопії була типовою. При проведенні дослідів використовували однодобові суспензії бактеріальних культур у фрізіологічному розчині та п'ятидобові культури грибів.

Для приготування суспензій бактеріальних культур і культури дріжджового гриба C. albicans мікробну масу змивали з поверхні поживного середовища стерильним суспендованим розчином, який містив 9 г/л натрію хлориду та переносили у стерильну пробірку, ретельно перемішували для рівномірного розподілення мікроорганізмів у зразку та доводили вміст до $10^{8}$ клітин/мл. Для приготування суспензії культури A. brasiliensis використовували стерильну суспендуючу рідину, що містить 9 г/л натрію хлориду P, 0,5 г/л полісорбат-80 Р, та доводили вміст спор до $10^{8}$ КУО/мл.

Із кожної отриманої суспензії, відразу після її приготування, відбирали проби і визначали кількість КУО в 1 мл кожної суспензії шляхом прямого висівання на чашки Петрі зі щільними поживними середовищами, які використовували для початкового вирощування тест-культур.

До кожного досліджуваного зразка додавали суспензію тест-мікроорганізмів у концентрації $10^{8}$ клітин/мл так, щоб у самому зразку мікробне навантаження становило від $10^{5}$ до $10^{6}$ КУО/мл.

Зразки витримували при температурі $20-25^{\circ} \mathrm{C}$ у захищеному від світла місці.

Розрахунки, як для лікарських засобів для зовнішнього застосування, здійснювали відповідно до вимог ДФУ (друге вид., том 1, п. 5.1.3) відразу після приготування зразків гелю і на 2-гу, 7-му, 14-ту та 28-му доби з моменту внесення мікроорганізмів у модельну систему [5]. Есрективність дії консервантів оцінювали

Таблиця 1

Властивості поживних середовищ

\begin{tabular}{|c|c|c|c|c|}
\hline \multirow{2}{*}{$\begin{array}{c}\text { Тест-штами } \\
\text { мікроорганізмів }\end{array}$} & \multirow{2}{*}{$\begin{array}{c}\text { Поживне } \\
\text { середовище }\end{array}$} & \multicolumn{2}{|c|}{ Умови культивування } & \multirow[b]{2}{*}{ Висновок } \\
\hline & & $\begin{array}{l}\text { температура, } \\
\text { C }\end{array}$ & $\begin{array}{c}\text { термін } \\
\text { культивування }\end{array}$ & \\
\hline $\begin{array}{l}\text { S. aureus } \\
\text { ATCC } 25923\end{array}$ & $\begin{array}{l}\text { Жовтково- } \\
\text { солевий агар }\end{array}$ & 37 & 24-48 год & $\begin{array}{l}\text { Морфрологія колоній і } \\
\text { клітин типова }\end{array}$ \\
\hline $\begin{array}{l}\text { E. coli } \\
\text { 055K59 №3912/41 }\end{array}$ & $\begin{array}{l}\text { Середовище } \\
\text { Ендо }\end{array}$ & 37 & 18-24 год & $\begin{array}{l}\text { Морфологія колоній і } \\
\text { клітин типова }\end{array}$ \\
\hline $\begin{array}{l}\text { P. aeruginosa } \\
\text { ATCC } 2853 \text { (F51). }\end{array}$ & $\begin{array}{l}\text { МПА, } \\
\text { середовище } \\
\text { Плоскірєва }\end{array}$ & 37 & 24 год & $\begin{array}{l}\text { Морфологія колоній і } \\
\text { клітин типова }\end{array}$ \\
\hline $\begin{array}{l}\text { C. albicans } \\
\text { ATCC 885-653 }\end{array}$ & Агар Сабуро & 25 & 5 діб & $\begin{array}{l}\text { Морфологія колоній і } \\
\text { клітин типова }\end{array}$ \\
\hline $\begin{array}{l}\text { A. brasiliensis ATCC } \\
16404\end{array}$ & Агар Сабуро & 25 & 5-7 діб & $\begin{array}{l}\text { Морфологія колоній і } \\
\text { клітин типова }\end{array}$ \\
\hline
\end{tabular}

ISSN 2312-0967. Фармацевтичний часопис. 2019. № 3 
у вигляді логарифрма (lg) зменшення числа життєздатних мікроорганізмів (МО) відносно визначеного вихідного числа МО.

Дані про консерванти, які входили в склад експериментальних зразків гелів, наведено в таблиці 2.

Результати й обговорення. Експериментально встановлено, що консерванти, які входили до складу досліджуваних гелів (табл. 2), у відповідних концентраціях та в умовах високого мікробного навантаження $10^{5}-10^{6}$ КУО/мл були ефективними проти як грам-
Фармацевтична технологія, біофармація, гомеопатія Pharmaceutical technology, biopharmacy, homeopathy позитивних та грамнегативних бактерій, так і проти дріжджоподібних грибів.

Результати щодо протигрибкової активності консервантів, присутніх у досліджуваних гелях, наведено в таблиці 3. Після 14-ти діб зберігання C. albicans у гелях 3 різними консервантами цей тест-штам не виявлено (табл. 3). Виняток становив гель без консерванту (зразок № 1), у якому рівень дріжджових грибів знижувався впродовж всього періоду експерименту: на 2-гу добу зниження логарифмму вихідного

\section{Таблиця 2}

Перелік і склад консервантів, введених до складу гелю

\begin{tabular}{|c|c|c|c|c|}
\hline № зразка & Назва консерванту & $\begin{array}{c}\text { Активний фрармацевтичний } \\
\text { інгредієнт }\end{array}$ & Вміст консерванту, \% & Країна- виробник \\
\hline 1 & \multicolumn{4}{|c|}{ Гель без консерванту } \\
\hline 2 & Ніпагін/ніпазол & \multirow{2}{*}{$\begin{array}{l}\text { Метилпарагідрокси } \\
\text { бензоат натрієва сіль / } \\
\text { пропілпарагідрокси } \\
\text { бензоат натрієва сіль }\end{array}$} & 0,2 & \multirow[t]{2}{*}{ Німеччина } \\
\hline 3 & Ніпагін/ніпазол & & 0,4 & \\
\hline 4 & Cosgard & $\begin{array}{l}\text { Бензиловий спирт, } \\
\text { дегідроацетова кислота }\end{array}$ & 0,4 & Німеччина \\
\hline 5 & Спирт френілетиловий & \multirow[t]{2}{*}{ 2-гідроксиетилбензол } & 0,25 & \multirow[t]{2}{*}{ Франція } \\
\hline 6 & Спирт френілетиловий & & 0,4 & \\
\hline 7 & Бензалконію хлорид & \multirow{2}{*}{$\begin{array}{l}\text { Алкілдиметилбензил амоній } \\
\text { хлорид }\end{array}$} & 0,02 & \multirow[t]{2}{*}{ Індія } \\
\hline 8 & Бензалконію хлорид & & 0,01 & \\
\hline
\end{tabular}

\section{Таблиця 3}

Результати дослідження ефективності консервантів з антимікробними властивостями у досліджуваних зразках гелів

\begin{tabular}{|c|c|c|c|c|c|}
\hline \multirow[t]{2}{*}{$\begin{array}{l}\text { № } \\
\text { зразка }\end{array}$} & \multirow{2}{*}{$\begin{array}{c}\text { Мікробне } \\
\text { навантаження після } \\
\text { інокуляції / lg КУО, } \\
\text { КУО/мл (lg КУО/мл) }\end{array}$} & \multicolumn{4}{|c|}{$\begin{array}{c}\text { Ріст мікроорганізмів, КУО/мл (Ig КУО/мл) } \\
\text { Логарифрм зниження вихідного мікробного навантаження }\end{array}$} \\
\hline & & 2 доба & 7 доба & 14 доба & 28 доба \\
\hline 1 & 2 & 3 & 4 & 5 & 6 \\
\hline \multicolumn{6}{|c|}{ S. aureus ATCC 25923} \\
\hline № 1 & \multirow{8}{*}{$4 \times 10^{5}(5,6)$} & $\begin{array}{c}5 \times 10^{4}(4,69) \\
\lg \text { зменш.0,91 }\end{array}$ & $\begin{array}{l}4,4 \times 10^{2}(2,64) \\
\lg \text { зменш.2,96 }\end{array}$ & $\mathrm{HB}$ & $\mathrm{HB}$ \\
\hline № 2 & & $\begin{array}{l}8,0 \times 10^{3}(2,9) \lg \\
\text { зменш. } 2,7\end{array}$ & $\mathrm{HB}$ & $\mathrm{HB}$ & $\mathrm{HB}$ \\
\hline № 3 & & $\begin{array}{l}1,1 \times 10^{3}(3,04) \lg \\
\text { зменш.2,56 }\end{array}$ & $\mathrm{HB}$ & $\mathrm{HB}$ & $\mathrm{HB}$ \\
\hline № 4 & & $\begin{array}{c}1,3 \times 10^{2}(2,11) \lg \\
\text { зменш.3,49 }\end{array}$ & $\mathrm{HB}$ & $\mathrm{HB}$ & $\mathrm{HB}$ \\
\hline № 5 & & $\begin{array}{c}3,1 \times 10^{2}(2,29) \lg \\
\text { зменш.3,31 }\end{array}$ & $\mathrm{HB}$ & $\mathrm{HB}$ & $\mathrm{HB}$ \\
\hline № 6 & & $\mathrm{HB}$ & $\mathrm{HB}$ & $\mathrm{HB}$ & $\mathrm{HB}$ \\
\hline № 7 & & $\begin{array}{l}5,7 \times 10^{3}(3,76) \lg \\
\text { зменш.1,84 }\end{array}$ & $\mathrm{HB}$ & $\mathrm{HB}$ & $\mathrm{HB}$ \\
\hline № 8 & & $\begin{array}{l}5,5 \times 10^{3}(3,74) \lg \\
\text { зменш.1,86 }\end{array}$ & $\mathrm{HB}$ & $\mathrm{HB}$ & $\mathrm{HB}$ \\
\hline
\end{tabular}

ISSN 2312-0967. Pharmaceutical review. 2019. № 3 
Фармацевтична технологія, біофармація, гомеопатія Pharmaceutical technology, biopharmacy, homeopathy

Продовження табл. 3

\begin{tabular}{|c|c|c|c|c|c|}
\hline 1 & 2 & 3 & 4 & 5 & 6 \\
\hline \multicolumn{6}{|c|}{ P. aeruginosa ATCC 2853 (F51) } \\
\hline № 1 & \multirow{8}{*}{$1 \times 10^{5}(5)$} & $\begin{array}{l}1 \times 10^{4}(4,00) \\
\lg \text { зменш.1,0 }\end{array}$ & $\begin{array}{l}1,8 \times 10^{1}(1,26) \\
\lg \text { зменш.3,74 }\end{array}$ & $\mathrm{HB}$ & $\mathrm{HB}$ \\
\hline № 2 & & $\begin{array}{c}2,5 \times 10^{3}(3,4) \lg \\
\text { зменш. 1,6 }\end{array}$ & $\mathrm{HB}$ & $\mathrm{HB}$ & $\mathrm{HB}$ \\
\hline № 3 & & $\begin{array}{c}1,2 \times 10^{3}(3,08) \lg \\
\text { зменш.2,78 }\end{array}$ & $\mathrm{HB}$ & $\mathrm{HB}$ & $\mathrm{HB}$ \\
\hline № 4 & & $\begin{array}{c}1,6 \times 10^{2}(2,2) \lg \\
\text { зменш. 2,8 }\end{array}$ & $\mathrm{HB}$ & $\mathrm{HB}$ & $\mathrm{HB}$ \\
\hline № 5 & & $\mathrm{HB}$ & $\mathrm{HB}$ & $\mathrm{HB}$ & $\mathrm{HB}$ \\
\hline № 6 & & $\mathrm{HB}$ & $\mathrm{HB}$ & $\mathrm{HB}$ & $\mathrm{HB}$ \\
\hline № 7 & & $\mathrm{HB}$ & $\mathrm{HB}$ & $\mathrm{HB}$ & $\mathrm{HB}$ \\
\hline № 8 & & $\begin{array}{c}4,3 \times 10^{1}(1,63) \lg \\
\text { зменш.3,37 }\end{array}$ & $\mathrm{HB}$ & $\mathrm{HB}$ & $\mathrm{HB}$ \\
\hline \multicolumn{6}{|c|}{ E. coli 055K59 №3912/41 } \\
\hline № 1 & \multirow{8}{*}{$2 \times 10^{5}(5,3)$} & $\begin{array}{c}3,2 \times 10^{4}(4,51) \lg \\
\text { зменш.0,79 }\end{array}$ & $\begin{array}{c}2,9 \times 10^{3}(3,46) \lg \\
\text { зменш.1,84 }\end{array}$ & $\begin{array}{r}4,5 \times 10^{2}(2,65) \\
\lg \text { зменш.2,65 } \\
\end{array}$ & $\begin{array}{c}2,7 \times 10^{1}(1,43) \lg \\
\text { зменш.3,87 }\end{array}$ \\
\hline № 2 & & $\begin{array}{c}5,2 \times 10^{3}(3,72) \lg \\
\text { зменш.1,58 }\end{array}$ & $\begin{array}{c}4,1 \times 10^{2}(2,61) \lg \\
\text { 3менш.2,69 }\end{array}$ & $\begin{array}{c}2,3 \times 10^{2}(2,36) \lg \\
\text { зменш. 2,94 }\end{array}$ & $\begin{array}{c}1,1 \times 10^{1}(1,04) \lg \\
\text { зменш. 4,26 }\end{array}$ \\
\hline № 3 & & $\begin{array}{c}6,7 \times 10^{3}(3,83) \lg \\
\text { зменш.1,47 }\end{array}$ & $\begin{array}{c}3,2 \times 10^{2}(2,51) \lg \\
\text { зменш. } 2,79\end{array}$ & $\begin{array}{c}5,5 \times 10^{1}(1,74) \lg \\
\text { зменш. } 3,56\end{array}$ & $\begin{array}{c}1,0 \times 10^{1}(1,0) \lg \\
\text { зменш. 4,3 }\end{array}$ \\
\hline № 4 & & $\begin{array}{c}7,9 \times 10^{2}(2,9) \lg \\
\text { зменш. } 2,4\end{array}$ & $\begin{array}{c}8,4 \times 10^{1}(1,92) \lg \\
\text { зменш.3,38 }\end{array}$ & $\begin{array}{c}1,1 \times 10^{1}(1,04) \lg \\
\text { зменш. 4,26 }\end{array}$ & $\mathrm{HB}$ \\
\hline № 5 & & $\begin{array}{c}2,1 \times 10^{3}(3,32) \lg \\
\text { зменш.1,98 }\end{array}$ & $\begin{array}{c}1,2 \times 10^{2}(2,08) \lg \\
\text { зменш.3,22 }\end{array}$ & $\mathrm{HB}$ & $\mathrm{HB}$ \\
\hline № 6 & & $\begin{array}{c}4,2 \times 10^{1}(1,62) \lg \\
\text { зменш.3,68 }\end{array}$ & $\mathrm{HB}$ & $\mathrm{HB}$ & $\mathrm{HB}$ \\
\hline № 7 & & $\begin{array}{c}5,3 \times 10^{2}(2,72) \lg \\
\text { зменш. } 2,58\end{array}$ & $\mathrm{HB}$ & $\mathrm{HB}$ & $\mathrm{HB}$ \\
\hline № 8 & & $\begin{array}{c}5,5 \times 10^{2}(2,74) \lg \\
\text { зменш. } 2,56\end{array}$ & $\begin{array}{c}5,3 \times 10^{1}(1,72) \lg \\
\text { зменш.3,58 }\end{array}$ & $\mathrm{HB}$ & $\mathrm{HB}$ \\
\hline \multicolumn{6}{|c|}{ C. albicans ATCC 885-653 } \\
\hline № 1 & \multirow{8}{*}{$2 \times 10^{5}(5,3)$} & $\begin{array}{c}9 \times 10^{4}(4,95) \\
\lg \text { зменш. 0,35 }\end{array}$ & $\begin{array}{r}4,2 \times 10^{3}(3,6) \\
\lg \text { зменш.1,7 } \\
\end{array}$ & $\begin{array}{l}3,1 \times 10^{2}(2,49) \\
\lg \text { зменш. 2,81 }\end{array}$ & $\begin{array}{c}1,3 \times 10^{1}(1,11) \\
\lg \text { зменш.4,19 }\end{array}$ \\
\hline № 2 & & $\begin{array}{l}8,0 \times 10^{3}(2,9) \\
\lg \text { зменш. } 2,4\end{array}$ & $\begin{array}{r}1,2 \times 10^{1}(1,08) \\
\lg \text { зменш.4,22 }\end{array}$ & $\mathrm{HB}$ & $\mathrm{HB}$ \\
\hline № 3 & & $\begin{array}{c}1,1 \times 10^{3}(3,04) \lg \\
\text { зменш.2,26 }\end{array}$ & $\mathrm{HB}$ & $\mathrm{HB}$ & $\mathrm{HB}$ \\
\hline № 4 & & $\begin{array}{c}1,3 \times 10^{2}(2,11) \lg \\
\text { зменш.3,19 }\end{array}$ & $\mathrm{HB}$ & $\mathrm{HB}$ & $\mathrm{HB}$ \\
\hline № 5 & & $\begin{array}{l}4,1 \times 10^{2}(2,6) \\
\lg \text { зменш. } 2,7\end{array}$ & $\begin{array}{c}1,9 \times 10^{2}(2,27) \lg \\
\text { зменш.3,03 }\end{array}$ & $\mathrm{HB}$ & $\mathrm{HB}$ \\
\hline № 6 & & $\begin{array}{l}3,2 \times 10^{2}(2,5) \\
\lg \text { зменш. } 2,8\end{array}$ & $\mathrm{HB}$ & $\mathrm{HB}$ & $\mathrm{HB}$ \\
\hline № 7 & & $\mathrm{HB}$ & $\mathrm{HB}$ & $\mathrm{HB}$ & $\mathrm{HB}$ \\
\hline № 8 & & $\mathrm{HB}$ & $\mathrm{HB}$ & $\mathrm{HB}$ & $\mathrm{HB}$ \\
\hline
\end{tabular}

ISSN 2312-0967. Фармацевтичний часопис. 2019. № 3 
Фармацевтична технологія, біофармація, гомеопатія Pharmaceutical technology, biopharmacy, homeopathy

Продовження табл. 3

\begin{tabular}{|c|c|c|c|c|c|}
\hline 1 & 2 & 3 & 4 & 5 & 6 \\
\hline \multicolumn{6}{|c|}{ A. brasiliensis ATCC 16404} \\
\hline № 1 & \multirow{8}{*}{$\begin{array}{c}2,5 \times 10^{5} \\
(5,39)\end{array}$} & $\begin{array}{r}3,0 \times 10^{4}(4,48) \\
\lg \text { зменш.0,91 }\end{array}$ & $\begin{array}{l}4,8 \times 10^{3}(3,68) \\
\lg 3 \text { менш.1,71 }\end{array}$ & $\begin{array}{l}2,6 \times 10^{2}(2,42) \\
\lg \text { зменш.2,97 }\end{array}$ & $\begin{array}{l}1,3 \times 10^{1}(1,12) \\
\lg \text { зменш.4,27 }\end{array}$ \\
\hline № 2 & & $\begin{array}{l}2,8 \times 10^{2}(2,88) \\
\lg \text { зменш.2,51 }\end{array}$ & $\begin{array}{l}4,4 \times 10^{1}(1,65) \\
\lg \text { зменш.3,74 }\end{array}$ & $\begin{array}{l}1,1 \times 10^{1}(1,04) \\
\lg \text { зменш.4,3 }\end{array}$ & $\mathrm{HB}$ \\
\hline № 3 & & $\begin{array}{l}2,8 \times 10^{2}(2,44) \\
\lg \text { зменш.2,95 }\end{array}$ & $\begin{array}{l}1,1 \times 10^{1}(1,04) \\
\lg \text { зменш.4,35 }\end{array}$ & $\mathrm{HB}$ & $\mathrm{HB}$ \\
\hline № 4 & & $\begin{array}{l}1,7 \times 10^{3}(3,22) \\
\lg \text { зменш.2.17 }\end{array}$ & $\begin{array}{l}2,7 \times 10^{2}(2,44) \\
\lg \text { зменш.2,95 }\end{array}$ & $\begin{array}{c}1,0 \times 10^{1}(1,0) \\
\lg \text { зменш.4,39 }\end{array}$ & $\mathrm{HB}$ \\
\hline № 5 & & $\begin{array}{c}1,3 \times 10^{2}(2,1) \\
\lg \text { зменш.3,29 }\end{array}$ & $\begin{array}{l}1,1 \times 10^{1}(1,04) \\
\lg \text { зменш.4,35 }\end{array}$ & $\mathrm{HB}$ & $\mathrm{HB}$ \\
\hline № 6 & & $\begin{array}{l}4,4 \times 10^{1}(1,65) \\
\lg \text { зменш.3,74 }\end{array}$ & HB & $\mathrm{HB}$ & $\mathrm{HB}$ \\
\hline № 7 & & $\begin{array}{c}6,3 \times 10^{2}(2,8) \\
\lg \text { зменш.2,59 }\end{array}$ & $\begin{array}{l}2,2 \times 10^{1}(1,34) \\
\lg \text { зменш.4,05 }\end{array}$ & $\begin{array}{l}1,0 \times 10^{1}(1,01) \\
\lg \text { зменш.4,3 }\end{array}$ & $\mathrm{HB}$ \\
\hline № 8 & & $\begin{array}{l}3,5 \times 10^{2}(2,54) \\
\lg \text { зменш. } 2,85\end{array}$ & $\begin{array}{l}3,6 \times 10^{1}(1,56) \\
\lg \text { зменш.3,83 }\end{array}$ & $\mathrm{HB}$ & $\mathrm{HB}$ \\
\hline
\end{tabular}

Примітка: НВ - мікроорганізмів не виявлено.

мікробного навантаження (lg) становило 0.35, на 7-му добу спостереження - 1.7, на 14-ту добу - 2.81, 28-му доби - 4.19, що не відповідає вимогам ДФУ. Найефективнішими щодо C.albicans були зразки № 7 та 8, які містили бензалконій хлорид. У них на 2-гу добу експерименту росту грибів не виявляли, що вказує на високий рівень антигрибкової активності даних консервантів у складі гелю. Найменш ефективним був консервант у зразку № 5 (спирт френілетиловий 0,25 \%), оскільки на 2-гу добу зниження логарифму вихідного мікробного навантаження становило 2.7, і лише на 14-ту добу росту грибів не було виявлено. Консерванти ніпагін/ніпазол (0,2 \%), «Cosgard» $(0,4 \%)$ та спирт френілетиловий $(0,4 \%)$ у зразках № 2, 4 та 6 проявили однакову дію проти C. albicans, росту не спостерігали починаючи із 7-ї доби експерименту.

Згідно з отриманими результатами, S. aureus не було виявлено вже на 14-ту добу інкубації тесткультури у зразках гелів із різними консервантами, що відповідає вимогам ДФУ (табл. 3). Найефрективнішим консервантом проти грампозитивних коків виявився спирт френілетиловий у концентрації 0,4 \% (зразок № 6), оскільки вже на 2-гу добу росту бактерій не спостерігали. Найменш активним проти золотистих стафрілококів був гель без консерванта (зразок № 1), оскільки на 2-гу добу зниження логарифмму вихідного мікробного навантаження становив 0.91, на 7-му добу - 2.96. Росту S. aureus у цьому зразку не виявлено на 14-ту добу. Усі інші зразки проявили однаково згубну дію на коки: їх загибель спостерігали на 14-ту добу.
Аналізуючи отримані експериментальні дані дослідження антимікробних властивостей зразків гелів щодо P. aeruginosa, слід зазначити, що спирт френілетиловий у концентраціях 0,25\% та 0,4\% (зразки № 5 та 6), а також бензалконію хлорид 0,02 \% (зразок № 7) виявилися найбільш ефрективними: життєздатних клітин не спостерігали після 2-х діб культивування. У зразку гелю без консерванту (зразок № 1) рівень життєздатних клітин $P$. aeruginosa впродовж дослідження поступово знижувався - на 2-гу добу експерименту значення логарифрму вихідного мікробного навантаження становило - 1.0, на 7-му - 3.74. При подальшому зберіганні цього гелю життєздатних клітин у даному зразку не виявлено. Консерванти ніпагін/ніпазол (0,2 та 0,4 \%), «Cosgard» $(0,4 \%)$, бензалконію хлорид $(0,01 \%)$ у зразках № $2,3,4$ та 8, відповідно, проявили однакову ефективність - росту не спостерігали, починаючи з 7-ї доби.

Результати, отримані стосовно A. brasiliensis (табл. 3), продемонстрували, що не усі зразки гелів відповідали вимогам ДФУ. Найефективнішим виявився спирт френілетиловий у концентрації 0,4 \% (зразок № 6). На 2-гу добу експерименту значення логарифму вихідного мікробного навантаження становило 3.74, а на 7-му добу росту мікроорганізмів не спостерігали. Консерванти ніпагін/ніпазол (0,4\%), спирт френілетиловий $(0,25 \%)$, бензалконію хлорид (0,01 \%) (зразки № 3, 5 та 8 відповідно) проявили однакову ефективність проти A. brasiliensis, росту не спостерігали вже 3 14-ї доби. Гель без консерванту (зразок № 1) виявив помірну протимікробну активність щодо

ISSN 2312-0967. Pharmaceutical review. 2019. № 3 
Фармацевтична технологія, біофармація, гомеопатія Pharmaceutical technology, biopharmacy, homeopathy

A. brasiliensis: впродовж всього періоду спостереження - на 2-гу, 7-му, 14-ту, 28-му доби значення логарифрму вихідного мікробного навантаження знижувалось та становило 0.91; $1.71 ; 2.97 ; 4.27$, відповідно, що підтвердило необхідність застосування консервантів. Консерванти ніпагін/ніпазол $(0,2 \%)$, «Cosgard» $(0,4 \%)$ та бензалконію хлорид $(0,02 \%)$ у зразках № 2, 4 та 7 проявили однакову ефективність, росту не спостерігали на 28-му добу, що не відповідало вимогам ДФу.

Гель без консерванту (зразка № 1) проявив помірну протимікробну активність щодо життєздатних клітин E. coli: впродовж всього періоду спостереження - на 2-гу, 7-му, 14-ту, 28-му доби, спостерігалось зниження логарифму вихідного мікробного навантаження на $0.79,1.84,2.65$ і 3.87 відповідно. Це свідчило також про неможливість використання гелю на основі водного витягу з ксенодерми та лідокаїну гідрохлоридом без консерванту.

Серед усіх дослідних зразків найбільш активними до даного тест-штаму виявились такі консерванти: спирт френілетиловий в концентрації 0,4 \% (зразок № 6) та бензалконію хлорид у концентрації 0,02 \% (зразок № 7). Активність консерванту ніпагін/ніпазол у концентрації 0,2 \% (зразок № 2) була недостатньою, адже логарифм зменшення життєздатних клі- тин E. coli не відповідав обом критеріям прийнятності ефрективності антимікробних консервантів. Збільшення концентрації консерванту вдвічі (зразок № 3) не зумовив значної зміни протимікробної активності, тому недоцільно його застосовувати в даній композиції. Консерванти «Cosgard» $(0,4 \%)$, спирт френілетиловий $(0,25 \%)$ та бензалконію хлорид $(0,02 \%)$ у зразках № 4, 5 та 8 відповідали усім критеріям ефективності, росту мікрофлори не спостерігалось на 14ту добу.

Висновки. Усі досліджувані консерванти (ніпагін/ ніпазол, «Cosgard», спирт френілетиловий, бензалконію хлорид) характеризуються різною активністю проти бактеріальних та грибкових референс-штамів мікроорганізмів у складі гелю з водним витягом із ксенодерми та лідокаїну гідрохлоридом.

За результатами проведених досліджень найбільш прийнятним консервантом обрано спирт френілетиловий у концентрації 0,4 \%, що зумовлено проявом його високої антимікробної активності у даній фрармацевтичній композиції, фрізіологічною безпечністю, економічністю, а також можливістю його використання як ароматизатора.

Конфрлікт інтересів: відсутній.

Conflicts of interest: authors have no conflict of interest to declare.

\title{
RESEARCH OF THE PRESERVATIVES' ANTIMICROBIC ACTIVITY FOR THE DEVELOPMENT OF A NEW COMBINED GEL COMPOSITION FOR THE LOCAL TREATMENT OF BURNS
}

\author{
B. V. Pavliuk ${ }^{1}$, O. Ya. Lukashiv ${ }^{2}$, O. V. Pokryshko ${ }^{1}$, M. B. Chubka ${ }^{1}$, T. A. Hroshovyi ${ }^{1}$ \\ I. Horbachevsky Ternopil National Medical University ${ }^{1}$ \\ Ternopil Scientific and Production Center for Standardization, Metrology and Certification ${ }^{2}$ \\ bohdana.vons@gmail.com
}

The aim of the work. Investigation of the preservatives antimicrobial activity in the gel samples based on water extraction from xenoderm and with lidocaine hydrochloride for topical treatment of burns.

Materials and Methods. The study used the method of evaluating the effectiveness of antimicrobial preservatives in accordance with the requirements of the State Pharmacopoeia of Ukraine. The following microorganisms were used as test cultures: Staphylococcus aureus ATCC 25923, Escherichia coli 055K59 №3912/41, Pseudomonas aeruginosa ATCC 2853 (F51), Candida albicans ATCC 885-653, Aspergillus brasiliensis ATCC 16404.

Results and Discussion. As a result of the conducted research, the effectiveness of the investigated antimicrobial preservatives (nipagine/nipazole, "cosgard", phenylethyl alcohol, benzalkonium chloride) of different concentrations in the gel samples based on water extraction from xenoderm and with lidocaine hydrochloride was established. The tested gel samples meet the requirements of the State Pharmacopoeia of Ukraine (second edition, volume 1, section 5.1.3) for the indicator "Antimicrobial preservative efficacy" for medicinal products for external use.

Conclusions. As a result of the conducted research, the most suitable preservative was selected phenylethyl alcohol at a concentration of $0.4 \%$, which is due to its high antimicrobial activity in this pharmaceutical composition, physiological safety, economy, and the possibility of its use as a flavoring.

Key words: gel; burns; preservatives; antimicrobial activity; microbiological studies.

ISSN 2312-0967. Фармацевтичний часопис. 2019. № 3 


\title{
ИССЛЕДОВАНИЕ АНТИМИКРОБНОЙ АКТИВНОСТИ КОНСЕРВАНТОВ С ЦЕЛЬЮ РАЗРАБОТКИ СОСТАВА КОМБИНИРОВАННОГО ГЕЛЯ ДЛЯ МЕСТНОГО ЛЕЧЕНИЯ ОЖОГОВ
}

\author{
Б. В. Павлюк ${ }^{1}$, О. Я. Лукашив ${ }^{2}$, О. В. Покрышко ${ }^{1}$ М. Б. Чубка'ㄹ, Т. А. Грошовый ${ }^{1}$ \\ Тернопольский национальный медицинский университет имени И. Я. Горбачевского МОз Украинь ${ }^{1}$ \\ ГП «Тернопольский научно-производственный чентр стандартизации, метрологии и \\ сертисрикации»² \\ bohdana.vons@gmail.com
}

\begin{abstract}
Цель работы. Исследование активности антимикробных консервантов в образцах гелей с водным извлечением из ксенодермы и лидокаина гидрохлорид для местного лечения ожогов.

Материалы и методы. При исследовании использовали методику оценки эфффективности антимикробных консервантов в соответствии с требованиями ГФУ. Как тест-культуры использовали следующие микроорганизмы: Staphylococcus aureus ATCC 25923, Escherichia coli 055K59 №3912/41, Pseudomonas aeruginosa ATCC 2853 (F51), Candida albicans ATCC 885-653, Aspergillus brasiliensis ATCC 16404.

Результаты и обсуждение. В результате проведенных исследований установлена эффеектиность исследуемых антимикробных консервантов (нипагин/нипазол, «cosgard», спирт френилэтиловый, бензалкония хлорид) различных концентраций в модельных образцах гелей с водным извлечением из ксенодермы и лидокаином гидрохлоридом. Исследуемые образцы гелей соответствуют требованиям ГФУ (второе изд., том 1, п. 5.1.3) по показателю «Эфрсективность антимикробных консервантов» для лекарственных средств для наружного применения.

Выводы. В результате проведенных исследований наиболее приемлемым консервантом избран спирт фенилэтиловый в концентрации 0,4 \%, что обусловлено его высокой антимикробной активностью в данной фрармацевтической композиции, сризиологической безопасностью, экономичностью, а также возможностью его использования в качестве ароматизатора.
\end{abstract}

Ключевые слова: гель; ожоги; консерванты; антимикробная активность; микробиологические исследования.

\section{Список літератури}

1. Вонс Б. В. Проблема лікування опікових травм та характеристика лікарських засобів для місцевого лікування опіків / Б. В. Вонс, М. Б. Чубка, Т. А. Грошовий // Актуальні питання фрармацевтичної та медичної науки та практики. - 2018. - Т. 11, № 1 (26). -C. 119-125. DOI: 10.14739/2409-2932.2018.1.123731

2. Noronha C. Local burn treatment - topical antimicrobial agents / C. Noronha, A. Almeida // Annals of Burns and Fire Disasters. -2000. - V. XIII, No 4. - URL: http:// www.medbc.com/annals/review/vol_13/num_4/text/ vol13n4p216.htm

3. Дослідження антимікробної активності консервантів 3 метою розробки вагінального гелю / М. Л. Бавикіна, Л. І. Вишневська, Т. П. Осолодченко [та ін.] // Управління, економіка та забезпечення якості в фрармації. - 2016. - № 1. - С. 8 - 13. Режим доступу до інфрормації : http://dspace.nuph.edu.ua/bitstream/123456789/8812/1/08-13.pdf

4. Горлачова В. І. Дослідження ефективності антимікробних консервантів з метою удосконалення

\section{References}

1. Vons BV, Chubka MB, Hroshovyi TA. [The problem of treatment of burns' wounds and characteristic of drugs for the local treatment of burns] Aktualni pytannia farmatsevtychnoi i medychnoi nauky ta praktyky. 2018;11(1): 119-25. Ukrainian. DOI: 10.14739/2409- складу лікарського косметичного засобу протизапальної дії / В.І. Горлачова, Л. І. Вишневська // Біофрармацевтичний журнал. - 2016. - № 1 (42). С. 16 -20. Режим доступу до інфрормації : http://dspace. nuph.edu.ua/bitstream/123456789/8826/1/16-20.pdf

5. Вивчення мікробіологічної чистоти деяких гелевих основ і рецептур з таурином / І. І. Бердей, О. І. Павх, Н. І. Волинська [та ін.] // Актуальні питання фрармацевтичної і медичної науки та практики. 2012. - № 1. - С. 48 - 50.

6. Ефективність антимікробнихконсервантів/Державна Фармакопея України: в 3 т. / Державне підприємство «Український науковий срармакопейний центр якості лікарських засобів». - 2-е вид. - Харків : Державне підприємство «Український науковий фармакопейний центр якості лікарських засобів», 2015. - T. 1. - C. 773 - 5. ISBN 978-966-96478-8-7

7. European Pharmacopoeia. European Directorate for the Quality of Medicines (EDQM). Strasbourg Cedex. $-9^{\text {th }}$ ed. - France: Council of Europe; 2016. -4016 p.

2932.2018.1.123731.

2. Noronha C, Almeida A. Local burn treatment - topical antimicrobial agents. Annals of Burns and Fire Disasters. 2000;XIII(4). Available from: http://www.medbc.com/ annals/review/vol_13/num_4/text/vol13n4p216.htm

ISSN 2312-0967. Pharmaceutical review. 2019. № 3 
Фармацевтична технологія, біофармація, гомеопатія Pharmaceutical technology, biopharmacy, homeopathy

3. Bavykina ML, Vyshnevska LI, Osolodchenko TP, Mehalinskyi VA. [Study of antimicrobial activity of preservatives with the aom of a vaginal gel design] Upr ekonomika ta zabezp yakosti v farmatsii. 2016;1: 8-13. Ukrainian. Available from: http://dspace.nuph. edu.ua/bitstream/123456789/8812/1/08-13.pdf

4. Horlachova VI, Vyshnevska LI. [Investigation of the effectiveness of antimicrobial preservatives to improve the structure of the medical cosmetic cream with anti-inflammatory action] Ukr biofarmats zhurn. 2016;1: 16-20. Ukrainian. Available from: http://dspace.nuph. edu.ua/bitstream/123456789/8826/1/16-20.pdf

5. Berdey II, Pavch OI, Volynska NI, Pokryshko OV, Soko- lova LV, Barna OM. [Study of microbiological purity of some gel bases and formulations with taurine] Aktualni pytannia farmatsevtychnoi i medychnoi nauky ta praktyky. 2012;1: 48-50. Ukrainian.

6. The effectiveness of antimicrobial preservatives I State Pharmacopoeia of Ukraine in 3 vol., 2nd edition. [Державна Фармакопея України: в 3 т.] Kharkiv: State Enterprise "Ukrainian Scientific Pharmacopoeial Center for Quality of Medicines"; 2015;1: 773-5. Ukrainian.

7. European Pharmacopoeia. European Directorate for the Quality of Medicines (EDQM). Strasbourg Cedex. $9^{\text {th }}$ ed. France: Council of Europe; 2016.

\section{Відомості про авторів:}

Павлюк Б. В. - аспірант кафедри управління та економіки фармації з технологією ліків, Тернопільський національний медичний університет імені І. Я. Горбачевського МОЗ України, Тернопіль, Україна. E-mail: bohdana.vons@gmail.com, ORCID 0000-0003-1276-0114

Лукашів О. Я. - канд. біол. наук, інженер випробувальної лабораторії, ДП «Тернопільський науково-виробничий центр стандартизації, метрології та сертифікації», Тернопіль, Україна. E-mail: lukashiv5@gmail.com, ORCID 00000002-5904-293X

Покришко О. В. - канд. мед. наук, доцент кафедри мікробіології, вірусології та імунології, Тернопільський національний медичний університет імені І. Я. Горбачевського МОЗ України, Тернопіль, Україна. E-mail: pokryshko@ tdmu.edu.ua

Чубка М. Б. - канд. фрармац. наук, доцент кафедри фрармації НHI післядипломної освіти, Тернопільський національний медичний університет імені І. Я. Горбачевського МОЗ України, Тернопіль, Україна. E-mail: chubkacom@gmail.com, ORCID 0000-0002-5666-5496

Грошовий Т. А. - д. фрармац. наук, профресор, завідувач кафредри управління та економіки фрармації з технологією ліків, Тернопільський національний медичний університет імені І. Я. Горбачевського МОз України, Тернопіль, Україна. E-mail: grochovuy@ukr.net, ORCID 0000-0002-6427-2158

\section{Information about the authors:}

Pavliuk B. V. - PhD student, Department of Pharmacy Management, Economics and Technology, I. Horbachevsky Ternopil National Medical University, Ternopil, Ukraine. E-mail: bohdana.vons@gmail.com, ORCID 0000-0003-1276-0114 Lukashiv O. Ya. - PhD (Biology), engineer at testing laboratory, SE "Ternopil Scientific and Production Center for Standardization, Metrology and Certification", Ternopil, Ukraine. E-mail: lukashiv5@gmail.com, ORCID 0000-0002-5904-293X Pokryshko O. V. - MD (Medicine), PhD, Associate Professor, Department of Microbiology, Virology and Immunology, I. Horbachevsky Ternopil National Medical University, Ternopil, Ukraine. E-mail: pokryshko@tdmu.edu.ua

Chubka M. B. - PhD (Pharmacy), Associate Professor, Pharmacy Department of Educational Scientific Institute of Postgraduate Education, I. Horbachevsky Ternopil National Medical University, Ternopil, Ukraine. E-mail: chubkacom@gmail. com, ORCID 0000-0002-5666-5496

Hroshovyi T. A. - DS (Pharmacy), Professor, Head of the Department of Pharmacy Management, Economics and Technology, I. Horbachevsky Ternopil National Medical University, Ternopil, Ukraine. E-mail: grochovuy@ukr.net, ORCID 00000002-6427-2158 